\title{
Optimization of social security contributions in health care
}

\begin{abstract}
Cost optimization in health care is based on starting enterprises that employ workers who, after full-time work, perform the same or similar activities for the employer. This violates the social security legislation and creates both legal and financial risks. Using the current regulations, as well as Supreme Court rulings and opinions contained in the publications, the present paper analyzes the legal aspects regarding the phenomenon observed in the labor market.
\end{abstract}

Keywords: jurisdiction, social security, health care, employer, employee, Poland.

DOI: $10.1515 /$ pjph-2016-0031

\section{INTRODUCTION}

Employers in the medical branch, in order to reduce staff costs often try to optimize social security payments of their own employees. The most common phenomenon involves creating enterprises hiring employees for contract work. This means, after they have worked full-time during the day, they perform the same or similar activities for their employer. The optimization is to consist in not having to pay contributions in respect of the contract work because the employee already pays contributions under the contract of employment.

Article 8, paragraph 2a of the Act of 13 October 1998, on social security system [1], specifies that an employee is also considered a person performing work under an agency contract, contract work or other contract for the provision of services, to whom, according to the Civil Code, the provisions relating to the contract work or contract for specific work, apply, if such a contract was concluded with the employer, with whom the person has the employment relationship, or if under that contract performs work for the employer, with whom they remain in the employment relationship.

This provision broadens the concept of an employee for the social security purposes beyond the sphere of employment relationship. This extension applies to two situations. The first is performing work under one of the contracts mentioned in the civil law, by a person who has entered into such a contract with the employer, while still remaining in an employment relationship. The second case involves performing work under of one of these contracts by the person who has entered into such a contract with a third party, but within the contract they perform work for the employer, with whom they have an employment relationship. For example, a non-public health care institution (NZOZ) sets up a limited liability company, which employs workers from NZOZ. The premise that determines regarding such a person as an employee within the meaning of the Act on the social security system is that as an employee related by the employment relationship with the employer, at the same time provides work for its benefit within the framework of a civil contract concluded with that employer or another person. Consequently, even if this person (the employee) has entered into a contract for specific work with a third party, this work is actually performed within the contract for the employer (the employer receives the results of the employee's work) $[2,3]$.

The primary effect of regarding the person referred to in Article 8 paragraph $2 \mathrm{a}$ as an employee, is covering the person with mandatory pension, disability, disease and accident insurance, as the employee (art. 6, paragraph 1 point 1, Article. 11 paragraph 1 and Art. 12 paragraph 1 of the Act on social security system). Therefore, the person is subject to the referral to these social insurance contributions. This obligation charges expenses to the contribution payer (Art. 36 paragraph. 1 and 2 of the Act on social security system).

Considering that the employer has to pay contributions for the employee (Art. 4, point 2 of the Act on the social security system), and the Art. 8, paragraph 2a, extends the concept of an employee for employee's further activity in the framework of a civil contract, if, within its framework, the employee performs work for the employer. Then, it is natural and consistent with the literal interpretation of this provision to recognize that also in the field of this sphere of activity, the employee should be considered for the purposes of social security as an employee of this particular employer.

The term "employee" usually is interpreted by reference to Art. 2 of the Labor Code [4]. Under this provision, a person is regarded an employee if they are employed under a contract of employment, appointment, election, nomination or a cooperative contract of employment, i.e. a person having employment 
relationship. The regulations of the Act on the Social Insurance System (for the purposes of this Act) formulate a legal definition of the term "employee". According to this definition, an employee within the meaning of the Act on the social insurance system is:

1. a person staying in the employment relationship,

2. a person performing work under an agency contract, contract work or other contract for the provision of services, to which according to the Civil Code, the provisions relating to the contract for provision of services or contract for specific work apply, if the contract was concluded with the employer, with whom the person remains in the employment relationship or if under that contract they perform work for the employer, with whom they have an employment relationship.

In the jurisprudence, there is an overall opinion that the phrase "work for the benefit of" was used in Art. 8 paragraph $2 \mathrm{a}$ of the Act on Social Security System (ASSS) in another sense than in the legal terminology, in which working "to the benefit of someone" can be performed by the existence of a specific legal relationship (legal attitude). In the context of the regulation of Art. 8 paragraph 2a, ASSS, this phrase describes the factual situation, which is characterized by the existence of the triangle of contracts, i.e.

1. a contract of employment,

2. a contract of mandate between an employee and a third party,

3. a subcontract between the employer and the ordering party.

The employer, as a consequence of subcontracting, ultimately takes the result of the work performed for the ordering party, which occurs as a result of concluding the contract of mandate/services with a third party and a civil contract concluded between the employer and the ordering party [5].

Further on, it is noted that the primary effect of regarding the person referred to in Article 8 paragraph 2a as an employee, is covering the employee with mandatory old-age pension insurance, disability insurance, sickness and accident insurance as an employee (Art. 6, paragraph 1 point 1, Article 11 paragraph 1 and Art. 12 paragraph 1 of the ASSS). Therefore, the employee is subject to the reporting to insurance in the full extent, and this obligation is borne by the premium payer (Art. 36 paragraph 1 and 2 of the ASSS). The payer is also required to calculate, settle and provide monthly contributions to the Social Insurance Institution (ZUS) (Art. 17, paragraph 1 of the ASSS). Contribution payers calculate portions of contributions for old-age pension, disability and sickness insurance financed by the insured and after deducting them from the insured persons' wages, transfer them to the Social Insurance Institution (Art. 17, paragraph 2 of the ASSS). Moving on to the heart of the matter, the Supreme Court noted [2] that when the civil contract is not concluded directly with the employee, but with a third party, and when that "external" entity concludes a civil law contract with the employee, nevertheless, the employer is paying contributions, even though a physical remuneration is paid by that third party. This interpretation is supported by the wording of Article 8, paragraph 2a of the Act, which requires treating the contractor as an employee of his/her employer and for the employee, in accordance with Article 4, point 2 of the Act, where the employer is the payer. Attention should also be paid to Art. 18 paragraph 1a of the ASSS. According to that article in which, in the case of insured persons referred to in Article 8, paragraph. 2a, to the basis of contribution rates for old-age pension and disability insurance, income from agency agreements, mandate or other service contract is taken into account, to which according to the Civil Code, there are applied provisions relating to the contract of mandate or specific work contract. Since the employer is the payer, and the income from a civil contract "is taken into account" on the basis for calculating contributions under the employment relationship, the employer, when setting the basis for calculation of social security contributions in respect of employment contract, should add up the wages from a civil contract with the remuneration from the employment relationship. In such a case as in the present case, i.e. when a specific triangle of agreements occurs, the fact that the employer must pay the contributions finds its legitimacy also in that the work within the framework of a civil contract is actually provided in his favor, and he gets the results of work and avoids burdens and responsibilities arising from the labor law. As the Supreme Court emphasized in another ruling [6], the aim of such regulation was to restrict the use of civil contracts by the employers for employing their own employees to perform the same tasks that they perform under the framework of the employment relationship. This was to bypass the limitations of protective labor laws and avoid the burden of social security contributions from these contracts. Secondly, the protection of workers against the effects of subjective fluctuations on the employers' part in the course of performing work by employees, consisting in transferring the employees by the parent employer to other entities (contractors). Then, they employ these workers under civil law contracts not covered by compulsory social insurance (specific task contract), or are exempted from this obligation in coincidence with the employment relationship (agency contract, mandate or other service contract, to which the provisions of the mandate apply). Thus, for the social security purposes, performing work under both civil law contracts concluded with the employer and concluded admittedly with a third party, but when the work is performed for the employer, is treated as work in the classic employment relationship - between the employee and the employer, also in the determination of the contribution payer. It is the most common way to optimize social security contributions by entities of the medical industry, especially non-public healthcare institutions.

A similar situation happens when a former employee establishes a business activity and acts in favor of the former employer. According to the justification of the draft law amending the law on social security system and some other laws of 1 July 2005 [7], adding of Art. 18a was to introduce preferential social security contributions for people who undertake an economic activity on their own account for the first time. Paying for 24 months of social security contributions from the contribution assessment basis equal to $30 \%$ of the minimum wage was intended to reduce the risks associated with taking the first economic activity, which would allow the allocation of such exempted funds for running and development of business. These preferences were designed for people who had no fixed sources of income (permanent job), from which contributions would be paid and who decided to start their business. This change was made to encourage start-ups and allocating savings for the purchase of machinery or raw materials, which in the case of health care translates into the purchase of diagnostic equipment, dental units or equipment of dental offices. 
However, running by a business (professional) activity in favor of a former employer by an entrepreneur cannot be recognized, because of having obtained qualifications to exercise independently these activities, as not corresponding to activities performed under an employment relationship, when the scope of obligations resulting from civil contract and the earlier executed employment contract is identical. Only determining that the rendered thus services to the former employer, do not correspond with the activities performed within the framework of the employment relationship, allows the use of preferential social security contributions. The phrase "doing business to a former employer for whom prior to starting a business in the current or preceding calendar year the activities were performed under an employment relationship or cooperative employment which fell within the scope of business activity" of Art. 18a of the Act, should, therefore, be referred to the activities of employment (duties) assigned by the employer and actually performed by the employee on a particular working post and not to all the actions that the employee may perform, e.g. due to holding qualifications, or to activities of the same or similar nature. Warsaw Court of Appeal in a similar case [8], or the Court of Appeal in Katowice [9], refer in the justifications to the case-law of the administrative courts: Regional Administrative Court in Gliwice, and the Regional Administrative Court in Poznan [10] relating to the interpretation of Art. 9a, paragraph 3 of the Act of 26 July 1991, on income tax from natural persons [11].

Referring to the indicated case law would be justified if the way of legal regulation contained in both standards (Art. 18a of the Act of Social Security and Art. 9a paragraph 3 of the Act on income tax from natural persons) were converging with each other. If it were so, the need to refer to the case law of the administrative courts should be accepted. Especially, in view of fully approved by the Court of Appeal, on the basis of tax law, position of the Supreme Administrative Court expressed in its judgment of 20 July 2010 [12]. Within that document, the Supreme Administrative Court pointed out that a normative phrase "corresponding to activities" contained in Article 9a paragraph 3 of the Act on income tax from natural persons, refers to revenues from providing services to the former or current employer, which are the same (identical) as the activities that the taxpayer or at least one of the partners performed under the employment relationship or cooperative employment. However, one can note that the way of legislation of both "regulations" is completely different, which just opens the way to construct this query. While the adjective "equivalent" means the same as "compatible", so much the phrase "falling within the scope" means the same as "housed in something, part of something, included in something." Consequently, according to the opinion issued by the Court representing the legal issue to be resolved, decoding of the phrase "were performing activities under an employment relationship, falling in the scope of business activity," seems to imply the need to perform within employment relationship not "the same" or "identical" activities with those covered by business activity, but at least certain activities that "correspond" to activities carried out within the business activity. Interpretation of the indicated phrase only in terms of its literal meaning means that performing for a former employer by the person running business of any activities covered by the previous contract of employment, would exclude the possibility of exercising the right to charge contributions for old-age and disability pension insurance during the first 24 calendar months from the date of commencement of business activity, from the calculation basis amounting to $30 \%$ of the minimum wage, pursuant to Art. 18a paragraph 1 of the Act. This interpretation seems to be consistent with the view expressed by the Supreme Court in the case I UK 323/09 (the first part of the thesis) [13]. In determining the proper interpretation of that provision, one cannot ignore the purpose that led the legislators when enacting the law. But the justification for this portion of the Act of 1 July 2005 amending the Act on the Social Security System and some other acts (Journal of Laws No. 150, item 1248) [14], which was introduced to the Act on Social Security System, Art. 18a, is very laconic. In support of the draft law, it is indicated that the amendment was intended to "encourage the start-up and to allocate saved sums for the purchase of machinery or raw materials for production." While analyzing this idea, it should be noted that this regulation was to encourage new people to activation by starting a business. The legislator, by introducing the above regulation aimed at facilitating market entry of all entities that were in a similar situation where it is difficult to compete with the established players in the market for a long time. Lawmakers also noticed that among the entities opening businesses there are such ones that after stopping the employment relationship establish cooperation with previous employers and on the basis of the transfer of part of the tasks previously carried out under employment relationship, begin to build their position in the market. These are undoubtedly privileged entities over those, which cannot take the advantage of such a possibility. The legislator, limiting thus the privilege of reduction of social security contributions for those entities, aimed to achieve a specific equality of opportunities. On the contrary, such entities in terms of market competition would benefit from unjustified preferences in relation to operators already established - using the double bonus (lower premiums and better conditions for setting up of business activity as providing regular employment), as well as to other entities newly created - better conditions to create business activity. On the other hand, the legislator wanted to prevent situations in which the employer forces termination of employment and encourages so called "self-employment", i.e. starting a business and running it on the basis of the duties previously carried out within the framework of the employment relationship. This is quite common, especially in the case of auxiliary and medical staff - medical duty shifts.

\section{CONCLUSION}

All things considered, it needs emphasizing that the legal consequences for any frauds related to the concluded contracts are threatening for the employer. In case Social Insurance Institution finds out that the employer is attempting at optimizing employment costs they would require an immediate payment of all outstanding and not overdue premiums plus interest for late payment. Moreover, Social Security Institution may impose an additional fee to the contribution payer up to $100 \%$ of unpaid premiums. In case of levy of execution, the enforcement costs and the costs of reminder are added. Persons who do not report employees are subject to criminal liability for an offense under Article 98 of the Act on the Social Security System. At the same time, if they do not pay premiums in the due amount, they may be subject to criminal liability under Art. $218 \S 1$ and 219 of the Criminal Code. 


\section{REFERENCES}

1. Dz.U. z 2007 r. Nr 11 poz. 74 ze zm.

2. Uchwała Sądu Najwyższego z dnia 2 września 2009 r. II UZP 6/09 Prok. i Pr. - wkł. 2010/11/44.

3. Hotłoś E. Glosa do uchwały SN z dnia 2 września 2009 r., II UZP 6/09; GSP-Prz. Orz. 2014:4;103-12.

4. Ustawa z dnia 26 czerwca 1974 r. Kodeks pracy (Dz.U. 2014.1502 j.t.).

5. Wyrok Sąu Apelacyjnego w Gdańsku z dnia 27 czerwca 2013 r., III A Ua 2027/12 Lex: 1342233.

6. Wyrok Sądu Najwyższego z dnia 3 kwietnia 2014 r., II UK 399/13, LEX nr 1458679).

7. Dz.U. z $2005 \mathrm{Nr} 150$, poz. 1248.

8. Wyrok Sądu Apelacyjnego w Warszawie wyrok z dnia 22 grudnia 2010 r., III A Ua 897/10 LEX:1120310.

9. Wyrok Sądu Apelacyjnego w Katowicach z dnia 23 sierpnia 2012 r. III A Ua 2719/11 LEX: 123653.

10. Wyrok Wojewódzkiego Sądu Administracyjnego w Poznaniu z dnia 1 marca 2007 r., I SA/Po 1138/06, LEX: 285717, Rzeczpospolita. PCD 2007:9;205

11. Dz.U. z 2000 r. Nr 14, poz. 176 ze zm.

12. Wyrok Naczelnego Sąu Administracyjnego w Warszawie z dnia 20 lipca 2010 r. II FSK 516/09 LEX: 610310.

13. Postanowienie Sądu Najwyższego z dnia 23 marca 2010 r. I UK 23/09LexLege: 179244 .

14. Dz.U. Nr 150, poz. 1248

\section{Corresponding author}

Jolanta Szymańska

Chair and Department of Pedodontics, Medical University of Lublin

7 Karmelicka Str., 20-081 Lublin

E-mail: szymanska.lublin@gmail.com

phone: +48601165205 